\title{
Forgotten Prosaic Works (Forming a Literary Image of the Holocaust in Slovak Literature of the 1940s and 1950s)
}

Abstract: Hučková Dana, Forgotten Prosaic Works (Forming a Literary Image of the Holocaust in Slovak Literature of the 1940s and 1950s). "Poznańskie Studia Slawistyczne" 12. Poznań 2017. Publishing House of the Poznan Society for the Advancement of the Arts and Sciences, pp. 153-166. ISSN 2084-3011.

The iconography of the Holocaust in Slovak literature between the late 1940s and mid-1950s was also created by texts that are almost forgotten today. The article discusses prosaic works by two Slovak writers. Some of these works belong to the early period of the Holocaust reception and some of them originated later. Literary history paid little or no attention especially to older works. One of the writers discussed in the article, Hela Volanská, disappeared from the literary life after 1970. The article discusses her works $O$ živých a mrtvych (On Those Who Are Alive and Dead, 1948) and Ako na cudzej svadbe (As at Somebody Else's Wedding, 1987/2009). The other writer discussed in this article, Ludo Zúbek, is an established name of Slovak literature, but is known mostly as an author of historical and biographical fiction, including a novel Jar Adely Ostrolúckej (Adela Ostrolúcka's Spring, 1957), which is today incorrectly considered literature for young female readers. Other Zúbek's works reached very little attention and acknowledgement. The article discusses his prosaic works Rozbitá dúha (Broken Rainbow, 1956) and Vltava (without date).

KEYWORDS: iconography of the Holocaust; the $20^{\text {th }}$ century Slovak literature; Volanská Hela; Zúbek Ludo

Taking into consideration a common state of Czechs and Slovaks, the theme of the Holocaust (Shoah) in Slovak literature went through several phases similar to those in Czech literature. A Czech literary historian Jiří Holý distinguishes several stages. The first one (1945-1949) is marked by immediate reactions of direct witnesses who survived the Holocaust. These reactions had a documentary character, and were based on survivors' own experience. Memoirs, diaries and letters were common genres. A change of the political regime in 1948 meant suppressing the theme of 
the Holocaust, since latent as well as obvious anti-Semitism was supported by the ideology. Instead of Jewish suffering in Nazi concentration camps, a heroic struggle of Communists against Fascists was emphasized. Works published in the 1950s marginalized or completely omitted Jewish identity of prisoners. In the late 1950s and early 1960s, the theme of the Holocaust appeared again. Holý sees a connection between the interest in the theme on the one side, and changes of the political atmosphere and liberalization of political life on the other side. After another political rupture (the so-called "normalization" in the 1970s), Communist ideology and anti-Semitism got in the foreground. A large number of works with the theme of the Holocaust was published in samizdat or abroad. Eventually, Jiří Holý considers the 1980s and 1990s as the second wave of interest in the theme, related to re-evaluating the past (Holý et al. 2011: 7-65).

A similar developmental line in depicting the theme of the Holocaust is also present in Slovak literature: from immediate documentary reactions, through personal experience, and later literary fiction, towards a re-evaluation of the theme emphasizing its topical aspects. The initial, documentary stage preferred literature of witnesses or victims rather than memoirs and diaries (memoirs began to be more common in the 1990s). The first anthology of Slovak literature on the Holocaust after 1989, entitled Božia ulička (Divine Lane; Richter 1998), edited by Milan Richter in 1998, proves the validity of J. Holý's classification. The anthology contains poems, prosaic works and essays by sixteen authors written between 1947 and 1997'. Another relevant criterion is a different attitude to the theme among authors of Jewish and non-Jewish origin. Slovak Jewish authors, if they remained in Czechoslovakia at all (many of them left the country before the Second World War, for example, Gejza Vámoš [Barborík 2006; Kročanová 1998: 30-39] in 1939; or left after the war, for example, Leopold Lahola in 1949), were silent because the period after the war was ideologically unfavourable. They might have wanted to forget the trauma, or they feared the anti-Semitism of the regime. From the 1950s onwards, non-Jewish Slovak writers have perceived the theme of the Holocaust as a crucial ethic

\footnotetext{
${ }^{1}$ There are works written by František Švantner, Rudolf Jašík, Leopold Lahola, Peter Karvaš, Ladislav Mňačko, Klára Jarunková, Vincent Šikula, Ján Johanides, Anton Baláž, Ivan Kupec, Iboja Wandall-Holmová, Tuvia Rübner, Ján Ondruš, Mikuláš Kováč, Milan Richter, and Juraj Špitzer.
} 
problem and a question of consciousness that one must deal with and speak about.

Researching the theme would probably start from a documentary brochure Oswienčim, hrobka štyroch miliónov l'udí (Auschwitz, a Grave of Four Million People) from 1945 written by Alfréd Wetzler. Almost twenty years later, in 1964, Wetzler wrote a novel Čo Dante nevidel (What Dante Did Not See), and published it under a pseudonym Jozef Lánik. Theatre plays and short stories by Leopold Lahola (real name Leopold Arje Friedmann) mark the initial literary (artistic) stage of the theme. Before his emigration to Israel in 1949, he wrote plays Bezvetrie v Zuele (Stillness in Zuela, 1947), Śtyri strany sveta (Four Sides of the World, 1948) and Atentát (Assassination, 1949), as well as short stories on pogroms Božia ulička (Divine Lane) and Vtáči spev (Birds Singing); both later included into a collection of stories Posledná vec (Last Thing, 1968) (Prušková 1996: 309-318).

Two texts from the late 1940s discuss how people refused to help Jews. A short story with a slight Existentialist hint Sedliak (Peasant, published in a posthumous collection Dáma, 1966) by František Švantner narrates how a potential rescuer, a nameless peasant, is unable to act altruistically, and instead of offering care to a sick and helpless Jewish doctor, he murders him (Kuzmíková 2000). Švantner showed in this story how the war and fear change human behaviour and how people in borderline situations, driven by the instinct of survival, commit crimes. Juraj Váh's theatre play (originally a radio play) Ticho (Silence) from 1948 shows the same situation but is set in a town in 1943. It covers one day when a Jewish person that escaped from a concentration camp comes to a villa of a wealthy state official. Even though he is their son's former classmate, the father sends him away, being afraid of family's safety (Robertsová 2007a: 153-167; on Juraj Váh, v. Váh 2013).

A list of works with the theme of the Holocaust from this period also contains a theatre play Návrat do života (Return to Life), written by Peter Karvaš, published and staged in 1949. It shows how a traumatic experience of a concentration camp prevents survivors from new life after the war ${ }^{2}$.

\footnotetext{
${ }^{2}$ For more information on trauma from concentration camps and difficulties integrating into life, v. Holý et al. 2011: 169-201.
} 
Last but not least, a documentary book Tragédia slovenských Židov (Tragedy of Slovak Jews) was published in 1949 (Steiner, Engel 1949).

Existing literary histories place a new return of the theme of the Holocaust in Slovak literature to the late 1950s, i.e. the period of the political thaw. This period is represented by works considered crucial for the theme today: Rudolf Jašík's novel Námestie svätej Alžbety (St. Elisabeth's Square, 1958), Mikuláš Kováč's poetry-choir with statements of victims Osvienčim 1958 (Auschwitz 1958, from a collection of verses Zem pod nohami, Earth Under Feet, 1960), Ján Ondruš' poems Osvienčimský oheň, Osvienčimský popol and Nemecká prehliadka 1944 (Fire of Auschwitz, Ashes of Auschwitz and German Examination 1944, published later in a collection Šialený mesiac, Crazy Moon, 1965), and Ladislav Mňačko’s novel Smrt'sa volá Engelchen (Death is Called Engelchen, 1963).

However, other works, today almost forgotten, also created the iconography of the Holocaust in the late 1940s and mid-1950s. This article discusses fiction by two Slovak writers. One of them, Hela Volanská, disappeared from literary life after 1970. The article discusses her works $O$ živých a mritvych (On Those Who Are Alive and on the Dead, 1948) and Ako na cudzej svadbe (As at Somebody Else's Wedding, 1987/2009). The other writer discussed in this article, Ludo Zúbek, is an established name of Slovak literature, but is mostly known as an author of historical and biographical fiction, including a novel Jar Adely Ostrolúckej (Adela Ostrolúcka's Spring, 1957), which is today incorrectly considered as literature for young female readers. Other works by him reached very little attention and acknowledgement. The article discusses his prosaic works Rozbitá dúha (Broken Rainbow, 1956) and Vltava (without date).

Hela Volanská (1912-1996), a Slovak writer of Jewish origin, adhered to a left-wing political orientation, and debuted twice. First in 1948 when she published a collection of short stories Stretnutia v lesoch (Meetings in Forests). Her books were only published in Slovak publishing houses until 1970. The second debut was in 2009, when her autobiographical prose Ako na cudzej svadbe (As at Somebody Else's Wedding) became available in Slovakia. This prose was included into a discussion on autobiographical genres, and it also inserted Volanská into the Slovak literary context again. 
Hela Volanská (real name Chaja Wolfowitz, married Friedmannová) was born in Poland (Lodz) in a Jewish family. She studied medicine at Comenius University in Bratislava. She graduated in 1940, after the war had broken up and the political situation had changed. She worked at a surgery ward of the State hospital in Žilina between 1941 and 1943. She was imprisoned for illegal Communist activities in Ilava, and as a Jew internated in a labour camp in Nováky. She joined the resistance movement in the camp. When the Slovak National Uprising broke out in autumn 1944, she became a member of a partisan group. After the war, she worked in trade unions, as a children's doctor and a writer. She lived in Bratislava, then moved to Prague but kept writing in Slovak. In the early 1950s, during political processes, when a new wave of anti-Semitism appeared, she was repeatedly interrogated.

Volanská depicted her experience from the war and the Uprising in a book of short stories Stretnutia v lesoch (Meetings in Forests, 1948). In her own words, she tried to "describe the experience from recent years in a bit more compact form" (Volanská 2009: 209) ${ }^{3}$. She used a method of idealized Realism, in order to promote a leading role of Communists in resistance movement and in social life. After years, she admitted that she had falsified the reality:

I meant to grasp the atmosphere of that era faithfully, and I omitted true episodes. I did not mention a Tatar who got a command to dig his own grave. I did not say a single word about commander's relation to prisoners. I censored my text myself, without other people's pressure, I distorted it, and I was silent about details that disturbed me. Yes, I had no idea about literature (Volanská 2009: 210) .

As a convinced and zealous Communist, she identified herself with an explanation that the fight for freedom was exclusively a Communist issue. She did not want to expose her party to any criticism of political opponents. She disagreed with several aspects of the post-war era, such as

3 “(...) trochu ucelenejšie vykreslit’ zážitky z nedávnych rokov”.

4 “(...) Mienila som vtedajšiu atmosféru vystihnút’ čo najpravdivejšie, a pravdivé epizódy som vynechala. Ani som nespomenula Tatára, ktorý si na rozkaz kopal hrob. Slovom som sa nezmienila o velitel'ovom vzt'ahu k zajatcom. Scenzurovala som svoj text sama, bez cudzieho nátlaku, skresl'ovala som, podrobnosti, ktoré ma znepokojovali, som zamlčala. Áno, nemala som šajnu o literatúre". 
excluding Jews from political life, doubting their participation in the fight for freedom, and the principle of collective responsibility.

One of the stories in the collection is entitled $O$ živých a mrtvych (On Those Who Are Alive and Dead). It is the only story dealing with the reality of a Jewish concentration camp in Nováky, reminding readers that "the law on concentration camps was printed with a seal of the Home Ministry

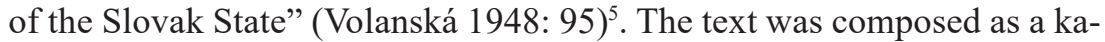
leidoscope of partisan's memories of other prisoners, who fought with him in the Uprising. Remembrance began when he saw a sheet of paper with names of the dead on which one name was crossed over and thus illegible. The narrator wishes to find out who this was, whether he/she was on the list by mistake, or whose death was kept silence about.

I cannot decipher names; words not alive grow, suddenly is it full of them here. They are lined up in rows and populate the forest. I am not alive, you are not alive, he/she is not alive. We are not alive... Yet we are alive, we are alive, only they are not alive. Who, who is the one whose name was crossed over? (Volanská 1948: 90) ${ }^{6}$.

Characters of the dead make the story crowded and individualize it. A question about who is and who is not alive is repeated. It leads to a statement about a will to life: “(...) we want to live, we all want to live!” (Volanská 1948: 101)7. This Existentialist moment denies a devastating force of the war and directs the protagonist towards future which requires a plan and a goal.

In her further works, Volanská chose different themes. Her works include a collection of stories Tajomstvo (Secret, 1950), a novel Jed (Poison, 1957), books of reportages Veno pre infantku (Dowry for the Infanta, 1959) and Kvet paprade (Fern Flower, 1961), as well as a collection of stories Planéty (Planets, 1965), a novel about the life of Polish emigration in Sydney Domino (1966), and a novel with a medical theme Siahni si, ako ma to boli (Touch to See How Much It Aches Me, 1970). In the early 1970s, she

\footnotetext{
5 “(...) zákon o koncentračných táboroch bol vytlačený s pečatou ministerstva vnútra Slovenského štátu”.

6“(...) Nelúštim už mená, Slová ne žije rastú, je ich tu naraz plno. Rovnajú sa do zástupov a zapĺńajú les. Nežijem, nežiješ, nežije. Nežijeme... Ale my žijeme, žijeme, len oni nežijú. Kto, kto je ten škrtnutý?".

7 “(...) chceme žit', všetci chceme žit!".
} 
became politically unwanted and a ban was issued on her works. In this period, she returned to the theme of the Holocaust. A samizdat publishing house in Prague, Petlice, published her autobiographical novel Concordia (1987). Later she published it in Czech translation with a title Cizi svadba (Somebody Else's Wedding, 1991) under her maiden name Chaja Wolfowitz. In German, the book was published as Wie auf einer fremden Hochzeit (1990). The novel only appeared in Slovak in 2009 under a title Ako na cudzej svadbe (As At Somebody Else's Wedding). Hela Volanská expressed in it her own traumatizing experience as a Polish Jewish girl and a young woman who survived a Slovak labour camp and the war. The title in Slovak repeats words of author's mother, who commented on her daughter's desire to have her Hebrew name changed (Chaja means hope) because Poles laughed at it. Instead, she wanted to have a Polish name Hela. "If you feel a shame for your own name, you feel as at somebody else's wedding through all your life (...) You should be proud that you are Jewish!" (Volanská 2009: 23) ${ }^{8}$. In a symbolical manner, the title of the novel also expresses one of author's predominant feelings, shared by the entire Jewish community - the feeling of distance, exclusion, constant danger and fear from anti-Semitic politics of different regimes.

Hela Volanská describes her life, her memories of the family in Poland, the years of the war in Slovakia, the 1950s in Czechoslovakia, her fear from political persecution and false accusations. She neutrally and objectively describes the partisan movement. She was a political commissar even though a Russian commander minded that she was Jewish: "This is a Slovak uprising, why Jews are here?" (Volanská 2009: 241) ${ }^{9}$. The leitmotif of the book is the reflection about how to stay firm and moral in the most difficult situations, how to act in accordance with the moral law, and how to avoid its violation (Baláž 2010). Volanská is aware that "the past is not a coat lining that you remove and throw away. Past is the bottom layer, an inseparable element of today" (Volanská 2009: 237) ${ }^{10}$. This is the reason why she writes about her personal experience with history. She submits

\footnotetext{
8 “'Ked' sa budeš hanbit' za vlastné meno, celý život sa budeš cítit' ako na cudzej svadbe. (...) Máš byt' hrdá, že si Židovka!”.

9 “Toto je slovenské povstanie, na čo sú tu Židia?".

10 “Minulost' nie je podšívka, ktorú odpáraš a zahodíš. Minulost' je spodná vrstva, neoddelitel'ná zložka dneška".
} 
her testimony about political manipulations, about evil and inhumanity of the times that claimed to build better future but limited instead elementary human freedom. Volanská's biographical narrative is generally determined by three basic ideological factors; namely, by racial persecution, Holocaust and political persecution. Her female perspective adds a gender aspect to the theme. The problem of women in the Holocaust became a research theme relatively late, in the 1980s; and in Slovakia, as an ethnographer Monika Vrzgulová writes, only recently (Vrzgulová 2011: 403). An essential precondition for gender studies about the Holocaust is awareness that "women and men reacted, experienced and «elaborated» the impact and consequences of racial persecution in different ways" (Vrzgulová 2011: 403-404). However, the way in which Volanská "experienced and reflected her own womanhood" (Vrzgulová 2011: 404) is significantly limited by an ideological filter that, in some parts of the text, completely suppresses it and moves it to the background. If a gender oriented interpretation perceives women in the Holocaust as "basically double victims - as women and as Jewish" (Vrzgulová 2011: 415), Volanská, in the context of depicting a post-war reality, adds a third dimension: victims of the Communist regime.

Ludo Zúbek (1907-1969) is considered a "dedicated describer of the national history" (Tomčík 1967), an author of non-fiction, as well as of historical and biographical stories and novels about representatives of Slovak culture, arts and history - for example, he wrote a book about a Gothic carver Paul from Levoča (Skrytý prameň [Hidden Source], 1956); and two works about a leader of the $19^{\text {th }}$ century Slovak revival Ludovít Štúr (Posledný zápas [Last Struggle], 1956, depicting the last days of his life and his death, as well as Jar Adely Ostrolúckej [Adela Ostrolúcka's Spring], $1957^{11}$, about Štúr's relation to a young noble woman). However, Zúbek was also interested in presence as his fiction works with the war theme prove: Mobilizácia, Rozbitá dúha, Vltava, Rukojemníci, and Tieňový obraz (Mobilisation, Broken Rainbow, Vltava, Hostages, and Shadow Picture). Except for one story, these texts were not published in Zúbek's lifetime.

${ }^{11}$ Zúbek’s novel Jar Adely Ostrolúckej (Adela Ostrolúcka's Spring) was translated into Polish under the title Wiosna Adeli. 
They were edited by a literary historian Milan Jurčo (Zúbek 1987) in 1987. Two years earlier Jurčo also published a monograph on L'udo Zúbek (Jurčo 1985). A new edition of Zúbek's stories, however, went almost unnoticed ${ }^{12}$.

Moral values are deeply rooted in Ludo Zúbek's work, as also his war stories show. Two of them relate to the theme of the Holocaust: Rozbitá duha (Broken Rainbow) and Vltava. The prehistory of the former one is set in the period before the disintegration of Austro-Hungarian monarchy, and the story continues by brief stops in the 1920s, 1930s and 1940s, showing life in a small Slovak town. The latter one describes an infernal setting of a concentration camp. Rozbitá dúha (Broken Rainbow) was published in 1956 in a weekly "Život” (Life). Zúbek used a mosaic of flashbacks to depict a relationship between two young people, both from non-Slovak families that, however, lived on the territory of present Slovakia for centuries. He showed their friendship in childhood, young man's hidden affection, and the story culminates in a scene of Jews being deported by Germans. The relation gets complicated since the ideology is perverted. A Jewish girl Erika is deported by her old friend and love, a German, Karol, who carries out his superiors' commands. Characters in the prose are model ones, and are determined by their social status. A young male protagonist experiences emotional confusion but the ideological pressure is stronger and he is unable to oppose it. As Milan Jurčo writes:

Rozbitá dúha (Broken Rainbow) is the most elaborated story out of all Zúbek's war stories. It is a symphony about love between two young people. Love that crashed to pieces, demolished by a harsh war reality before it could develop. In no other Zúbek's work one can find such a sensitive and artistic depiction of a relation of two people on the cusp between childhood and adulthood. Their unclear desires do not have a concrete shape yet (...) Sensed love stops understanding itself when somebody else's will penetrates into its magic circle (Jurčo 1987: 265) 13. $^{13}$.

${ }^{12}$ The book had a similar destiny as many other works that a literary historian Dagmar Kročanová-Robertsová covers in her research of theatre and drama between 1945 and 1949, in a monograph Nerozrezaná dráma (Uncut Drama). Since she was the first reader of plays that had been published decades ago but had not been read yet, she had to cut pages of the original editions (v. Robertsová 2007b: 3). My experience with Zúbek's book from 1987 is similar.

13 “Novela Rozbitá dúha je zo všetkých Zúbkových vojnových próz umelecky najprepracovanejšia. Je to symfónia lásky dvoch mladých l’udí. Lásky, ktorá sa rozbíja na márne kúsky nárazom o tvrdú vojnovú realitu skôr, ako sa stihla rozvinút'. Nikde inde v Zúbkovej tvorbe nenájdeme tak výsostne umelecky zvládnutý a subjektívne hlboko precítený vzt’ah 
Zúbek shows a borderline situation and, at the same time, he modifies a model of Romantic literature (love with obstacles) by implementing problematic and ideological elements.

Even though Erika and Karol have a different social background, nationality, religion and values, they are still close one to another. Only under the pressure of Nazi ideology, which Karol absorbs through education, they get divided by the concept of the race. Karol becomes Karl, he joins Hitler-Jugend, and his hatred of Jews supposedly indicates his political maturity. Even though he admires Erika and is fascinated by her erotic beauty (that she is not aware of), he believes in the rhetoric of racial superiority and ideological prejudice. A political aspect wins in his dilemma. His secret love changes into harshness, and weak Karol publically states that he hates a "damn Jew". His character is more individualized in the story than hers: he is dynamic, contradictory, ambiguous, and clearly negative in the end. In Karol, Zúbek showed how ideology deprives humans of their ability to feel solidarity with others, to overcome prejudice and to act morally that is, in accordance with their own feelings.

The other story, Vltava, is set in a concentration camp. It got preserved among Zúbek's manuscripts. It was not dated and was only published in 1987. Its plot is dramatic: one of female prisoners, a former ballet dancer of the National Theatre in Prague, has to dance on the $28^{\text {th }}$ October (the anniversary of founding Czechoslovak Republic) on the Appelplatz to the music of the second symphony Vltava from the cycle Má vlast (My Homeland) by a Czech composer Bedřich Smetana. The commander enjoys the dance whereas the prisoners suffer.

Only a brain of a perverted person dulled by cruelty could think of this kind of emotional torture. Perhaps they wanted to make a beloved composition profane, perhaps they wanted that the melody dear to all tear to pieces aching hearts, perhaps they wanted to show their understanding of aesthetic values - whatever the reason was, they succeeded (Zúbek 1987: 152) ${ }^{14}$.

dvoch mladých l’udí na rozhraní detstva a dospievania. Nejasné túžby ešte nemajú konkrétny tvar (...) Tušená lúbost' si sama prestáva rozumiet', ked’ do jej magického čarokruhu preniká cudzia vôla".

14 “Iba krutost’ami otupený mozog perverzného človeka mohol si vymysliet' takýto druh duševných múk. Azda chceli sprofanizovat' milovanú skladbu, azda chceli rozdrásat' ubo- 
The last tones of the composition mean dancer's death. The commander, a person with no conscience and morals, enjoys humiliation and shoots the dancer in front of other prisoners' eyes.

Everything must have been thought through before - with a German preciseness and punctuality. The music was over. It is not the end yet though. After a short dramatic pause, the composition is completed by two strong accords. Like two beats. Two exclamation marks to emphasize the conclusion. After this brief pause that created a bridge between life and death, those scary exclamation marks were heard. They echoed because two shots from a gun made sounds of tympani stronger. Dry, roaring, as if they spoke human speech, those two maledicted words: Los! Los! (Zúbek 1987: 157-158) ${ }^{15}$.

However, the prisoners perceive the tragic dance as an expression of the desire for freedom, as a spark of hope, a reminiscence of distant home, an imprint that enabled them to overcome their lethargy and apathy caused by inhuman, infernal conditions of the camp.

The story contains a strong humanistic message: arts opposes death, since it is capable to defeat inhumanity and to give rise to the hope of new life. Music brings light to the darkest reality. According to Milan Jurčo,

Zúbek realized that the choice of the theme matters if a work of art is to influence beings on the edge between life and death. He chose a music work with a theme of homeland. However, he did not get satisfied by this. He knew that he had to contrast a human struggle for an artistic shape to a struggle with immense despair (Jurčo 1987: 267) ${ }^{16}$.

This struggle for an artistic shape was represented by an inner monologue of the ballet dancer commenting on her improvisation and looking for adequate expression of music.

lené srdcia melódiou nad všetko drahou, azda chceli ukázat'svoje pochopenie pre estetické hodnoty - nech bolo akokol'vek, efekt sa vydaril".

15 "Všetko bolo istotne už vopred premyslené a pripravené s diabolskou - nie, to je slabý výraz! - s nemeckou dôkladnost'ou a presnost'ou. Hudba doznela. Ale ešte nie je koniec. Po krátkej dramatickej pauze zavíšia skladbu dva strohé akordy. Akoby dva údery. Dva výkričníky na zvýraznenie záveru. Po tej kratučkej pauze, ktorá sa stala mostom medzi životom a smet'ou, zazneli tie strašidelné výkričníky. Zazneli zdvojene, lebo zvuky tympanov zosilneli dva výstrely z revolvera. Sucho, štekavo, akoby aj ony hovorili l'udskou rečou tie dve prekliate slová: «Los! Los!»”.

16 “Zúbek si však uvedomil, že záleží už na vol'be témy, ak má umelecké dielo zapôsobit' na bytosti potácajúce sa na hranici života a smrti. Rozhodol sa pre hudobné dielo s témou vlasti. No neuspokojil sa s tým. Vedel, že do zápasu s bezhraničným zúfalstvom musí postavit' aktuálny zápas človeka o umelecký tvar". 
She felt as a violin player on a stage in front of demanding audiences, with a violin that only had one string. So what! With one string, she will try to produce a melody that will make heart sing and soul cheer even when eyes cry. She must produce that miracle, if not for herself, then for these audiences. She has not ever had audiences like that and there were few artists in the world that would have similar audiences (Zúbek 1987: 153$)^{17}$.

The ballet dancer finds inner strength to express particular music motifs with her weak body - grace of a running doe, bickering water, cheerful village dance... She reaches ecstasy when she uses all her creativity in order to mediate the message of a national composer through her dance. Zúbek mediates her effort into the language of literature. For her effort, she is rewarded by energy and hope of other prisoners who seem living shades rather than people. She dies because commander's refined perversity requires her death. This conclusion confirms a statement from the beginning of the story, that "in no other place human lives are worth as little as here in a concentration camp" (Zúbek 1987: 149) ${ }^{18}$.

Zúbek focused on the force of aesthetic impression, even though produced in inhuman and immoral surroundings. Combining facts and fiction, he showed a connection between music and dance, symphony and ballet dance as elements that stimulated deprived people and gave them new hope. In his story, he was able to show all elementary aspects of the Nazi ideology in concentration camps, such as the loss of prisoners' identities; no respect for and annihilation of human dignity; people's isolation; treating people as if they never existed; situations, in which a punishment has no connection with a crime; and others.

Both Hela Volanská and Ludo Zúbek in their works expanded the register of topoi, motifs and images related to a literary representation of the Holocaust. Volanská shifted from her initial position (literature of witnesses and victims) to memoirs preserving memory, and bringing messages about

17 “Cítila sa ako huslista stojaci na pódiu pred náročným obecenstvom s husl'ami a len jednou strunou na nich. Ale nech! Pokúsi sa na tejto jedinej strune vylúdit' melódiu, pri ktorej bude srdce spievat' a duša jasat' - i ked' oči budú plakat'. Musí vyčarit' zo seba ten zázrak, ak nie pre seba, tak pre toto obecenstvo. Takéto ešte nikdy nemala a na svete by sa našlo málo umelcov, ktorí by vystupovali pred podobným obecenstvom".

18 "Nikde nie sú l'udské životy také lacné ako tu v koncentračnom tábore". 
horrors, suffering and cruelty produced by people's fidelity to ideology. Zúbek, without having personal experience from the Holocaust, developed autonomous artistic statements from the beginning of his literary career. Both writers, however, emphasized that the theme of the Holocaust was not an issue of the past. Instead, it must remain a constant part of historical and national memory available also through literature. Even though in different times and in a different milieu, they came to the conclusion very similar to the one expressed by a Hungarian writer Imre Kertész (2002), namely, if people in presence want to overcome the trauma of the Holocaust, they have to face history of their own nation. Only a return to the past and an identification with historical experience, no matter how unpleasant and tragic it was, leads to knowledge and catharsis. Although historical approach to the Holocaust can offer neither explanation nor understanding, it is necessary because only self-reflection leads to purification.

According to a historian Ivan Kamenec, in the period of the Communist regime, problems of the Holocaust were more reflected in arts: in literature, poetry, drama, film, music and visual arts... Artistic works with this problem thus, to some extent and with a necessary toleration of artistic concession, substituted the knowledge about the Holocaust which Slovak public should have received, first of all, from historians. Nevertheless, an artistic depiction of the Holocaust was very important for the consciousness of the society in existing conditions (Kamenec 2009: 65). Although H. Volanská and L. Zúbek's texts had different motivations and publishing destinies, in this sense they played an essential part in an initial construction, and later also in a revival of historical memory, as well as in coping with historical traumas through arts.

\section{Literatúra}

Baláž A., 2010, Ako na cudzej svadbe, in: “Knižná revue” No. 1.

Barborík V., 2006, Prozaik Gejza Vámoš, Bratislava.

Holý J. (ed.), 2007, Holokaust v české, slovenské a polské literatuře, Praha.

Holý J., Málek P., Špirit M., Tomáš F., 2011, Šoa v české literatuře a v kulturní paměti, Praha.

Jurčo M., 1985, Dielo Luda Zúbka, Bratislava.

Jurčo M., 1987, Objavovatel' i tvorca krásy, in: L'. Zúbek, Zo zamknutej záhrady, ed. M. Jurčo, Bratislava, pp. 253-271. 
Jurčo M., 2006, Pod pokojnou hladinou zvíchrená citovost' (Vývinové portrétovanie Luda Zúbka), in: M. Jurčo, Z prelomu storočí, z rozhrania žánrov. Tvorcovia a diela (v) zovretí dobou, Martin.

Kamenec I., 2008, Fenomén holokaustu v historiografii, v umeleckej tvorbe a vo vedomi slovenskej spoločnosti, in: Holokaust ako historický a morálny problém v minulosti a súčasnosti. Súčasný stav výskumu, Bratislava-Mojmírovce.

Kamenec I., 2005a, Holokaust na Slovensku, jeho reflexie v literatúre a spoločnosti, “Terezínské listy" Vol. 33, pp. 82-89.

Kamenec I., 2005b, Sedemdesiattisic Židov. Holokaust na Slovensku, jeho reflexie v literatúre a spoločnosti, "OS - Občianska spoločnost”" No. 1-2, pp. 14-22.

Kamenec I., 2009, Reflexia holokaustu v slovenskej spoločnosti a literatúre. In: Spoločnost'. Politika. Historiografia. Pokrivené (?) zrkadlo dejín slovenskej spoločnosti $v$ dvadsiatom storočí. Bratislava, Historický ústav SAV, pp. 61-68.

Kertész I., 2002, Vyhnaný jazyk, Bratislava.

Kročanová D., 1998, Gejza Vámoš, in: Portréty slovenských spisovatel’ov 1, Bratislava, pp. 30-39.

Kuzmíková J., 2000, František Švantner. V zákulisi naturizmu, Bratislava.

Prušková Z., 1996, Vyslovitel’nost' nevyslovitel'ného alebo štrnást' noviel Leopolda Laholu. Tri poznámky a pokus o výklad, "Česká literatura” Vol. 44, No. 3, pp. 309-318.

Richter M. (ed.), 1998, Božia ulička. Antológia slovenskej literatúry o holokauste, Bratislava.

Robertsová D., 2007a, Návraty, križovatky a cesty: Holokaust v slovenskej dráme v obdobi 1945-1949, in: Holokaust v české, slovenské a polské literatuře, ed. J. Holý, Praha, pp. 153-167.

Robertsová D., 2007b, Nerozrezaná drama: o slovenskej dráme a divadle v rokoch 1945-49, Bratislava.

Salner P., 1997, Prežili holocaust, Bratislava.

Steiner B., Engel S., 1949, Tragédia slovenských Židov: fotografie a dokumenty, Bratislava.

Tomčík M., 1967, Oddaný zobrazovatel' národných dejín, in: L. Zúbek, Skrytý prameň, Bratislava.

Váh J., 2013, Súborné dramatické dielo I. Divadelné hry, ed. D. Kročanová, Bratislava.

Volanská H., 2009, Ako na cudzej svadbe, Bratislava.

Volanská H., 1948, Stretnutia v lesoch, Praha-Bratislava:

Vrzgulová M., 2011, Holokaust v životných príbehoch žien, in: Na ceste $k$ modernej žene. Kapitoly z dejín rodových vztahov na Slovensku, ed. G. Dudeková, Bratislava, pp. 403-423.

Zúbek L., 1987, Zo zamknutej záhrady, ed. M. Jurčo, Bratislava. 